\author{
F. M. Raimondo, P. Mazzola \& V. Spadaro
}

\title{
A new species of Smyrnium (Apiaceae) related to $S$. perfoliatum
}

\begin{abstract}
Raimondo, F. M., Mazzola, P. \& Spadaro, V.: A new species of Smyrnium (Apiaceae) related to $S$. perfoliatum. - Fl. Medit. 25: 137-142. 2015. — ISSN: 1120-4052 printed, 2240-4538 online.

On the basis of plant collections recently carried out in Sicily as well as the study of the herbarium material kept in PAL and PAL-Gr, a new species of Smyrnium (Apiaceae) is described here. This new taxon, named Smyrnium dimartinoi, is related to S. perfoliatum and is presently known from Sicily, Crete and realistically elsewhere in the Mediterranean. In such range it occurs in open woods and clearings of the Mediterranean-temperate and submontane belt.
\end{abstract}

Key words: Smyrnium, taxonomy, vascular plants, Sicilian flora, European flora.

\section{Introduction}

Smyrnium L., an Eurasian genus of the family Apiaceae, includes about 20 taxa of which, according to Gómez (2003), only 7 are accepted at specific rank, and, among these, 5 are native to Europe (Tutin 1968; Gomez 2003). In the Italian flora, the genus is represented by 3 taxa also occurring in Sicily (Pignatti 1982; Giardina \& al. 2007). These are: Smyrnium olusatrum L., S. perfoliatum L. and S. rotundifolium Mill. The last one has also been treated at the rank of subspecies under S. perfoliatum [S. perfoliatum subsp. rotundifolium (Mill.) Hartvig] (Strid 1986; Conti \& al. 2005) or as a mere variety (Fiori 1924). Unlike the other two, S. olusatrum occurs throughout most of the Sicily, often associated to nitrophilous habitats; $S$. perfoliatum occurs in the underwood of deciduous Quercus sp. pl. and Fagus sylvatica L. woods, in the submontane and montane belts of the Nebrodi mountains. S. rotundifolium is instead common in some less mesophylous environments like thermophylous open woodlands of central and western Sicily. In this part of the island, the populations related to $S$. perfoliatum, especially on the Mountains around Palermo, diverge for both morphological and ecological characteristics. In particular, plants corresponding to $S$. perfoliatum subsp. perfoliatum only in the underwood of Quercus and Fagus woods in the Nebrodi mountains occur, under mesophylous conditions. Dissimilar forms that are rather intermediate with respect to $S$. rotundifolium instead occur in C-W Sicily (Madonie and mountains south of Palermo). The study of the morphological characters - namely the leaf, stem and fruit - makes possible to clearly distinguish these pop- 
ulations that, therefore, represent a taxonomically and perhaps even chorologically critical case, since similar plants of Greece were described as S. rotundifolium var. ovatifolium Halàcsy (Halàcsy 1901).

\section{Materials and methods}

Specimens from Sicily doubtfully referred to S. perfoliatum, and several others from SItaly and some other European countries kept in PAL and PAL-Gr, are examined from the morphological and chorological points of view. The original material and other studied specimens of the related taxa cited above are housed in BM, LINN, P and WU (Fig. 1).

According to the remarks explained in the introduction, the herbarium material referred to $S$. perfoliatum has been studied in deep, and it has been stated that it partly agrees with $S$. rotundifolium var. ovatifolium Halàcsy. The same conclusion has been drawn with respect to the Sicilian material.

\section{Results}

Taking into account the discriminant characters found with respect to both $S$. rotundifolium and S. perfoliatum - that apparently are quite distinct species - the critical populations studied are referred to a new specific taxon here named Smyrnium dimartinoi.

Smyrnium dimartinoi Raimondo, Mazzola \& Spadaro, sp. nov. (Fig. 1a) Incl. S. perfoliatum var. ovatifolium Halàcsy

Diagnosis: Herba biennis, glabra, $60(70) \mathrm{cm}$ attingens; brevi radice napiforme praedita. Caulis cylindraceus, nudus. Folia basilaria laciniata, folia caulinaria ternata ad basim, simplicia ad apicem, ovata, marginibus crenulatis. Fructus minusculus (2-3 mm), nigricans.

Typus: Sicily: Val dei Conti, near Ficuzza (Palermo), 37 53'48” N $13^{\circ} 23^{\prime}$ 07” E, $600 \mathrm{~m}$ a.s.1., undergrowth on nitrified sandstone soil, 20.6.2013, F. M. Raimondo s.n. (Holo: PAL!). Isotypi in PAL!, PAL-Gr! and FI!

Description: Biennial herb, up to 60 (70) cm high. Stem sub-cylindrical. Root turnipshaped. Basal leaves laciniate; lower stem leaves ternate; middle and upper leaves simple, sessile, ovate, with crenulate margins, the lowest is three-lobed. Flowers yellowish; almost regular many-flowered umbel. Fruits 2-3 mm, roundish, blackish when ripe.

Phenology: flowering May-June, fruiting June-July.

Distribution: Sicily, Crete and realistically elsewhere in the Mediterranean area (Fig. 2).

Ecology: Smyrnium dimartinoi frequently occurs in cool and more or less shadowy places, on both siliceous or limestone nitrophilous substrata in the temperate and sub-montane belt. 

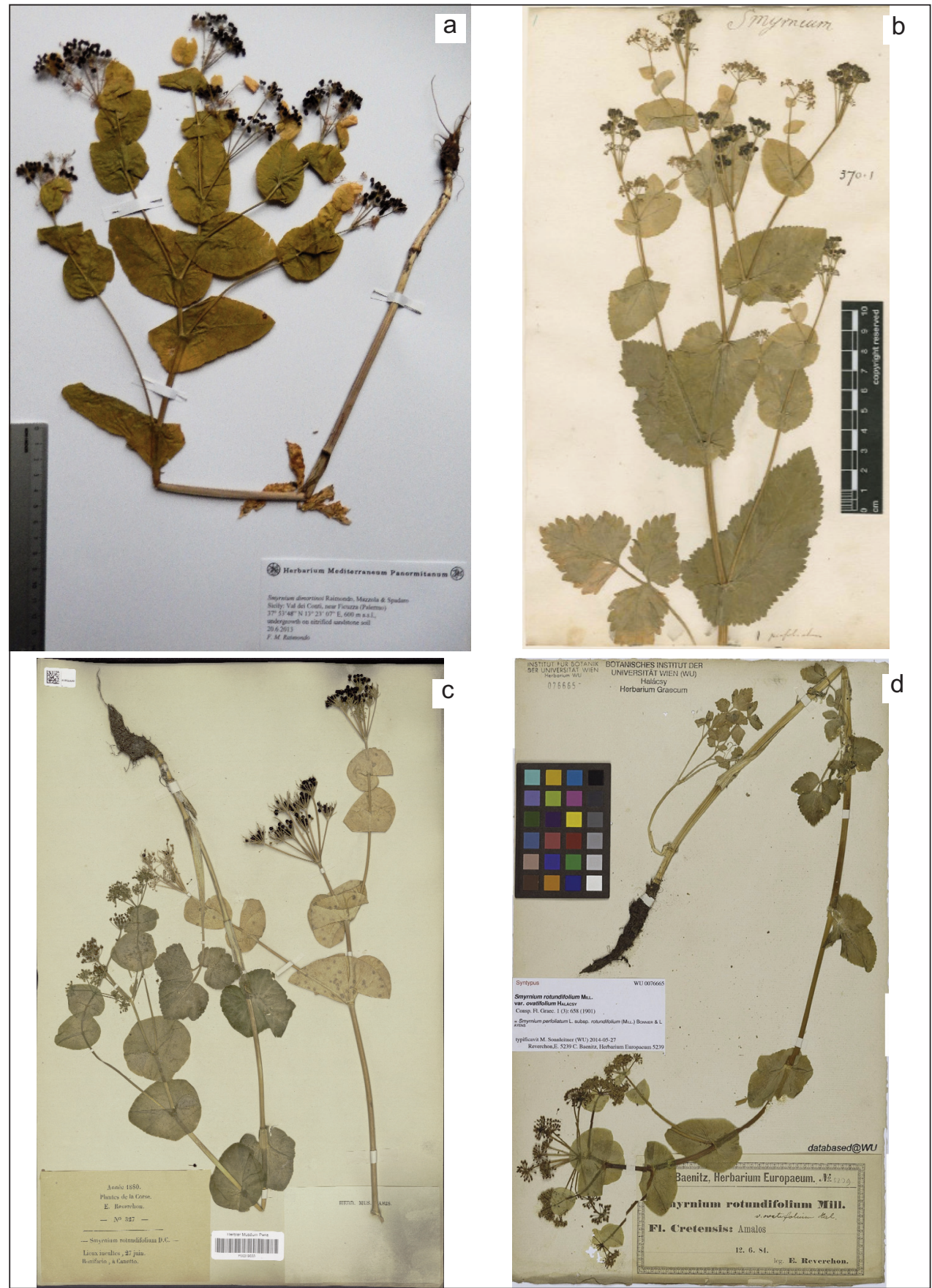

Fig. 1. Comparison between the studied taxa: a) holtype of Smyrnium dimartinoi (PAL); b) Lectotype of $S$. perfoliatum (LINN); c) S. rotundifolium (P) d) original meterial of S. rotundifolium var. ovatifolium (WU). 


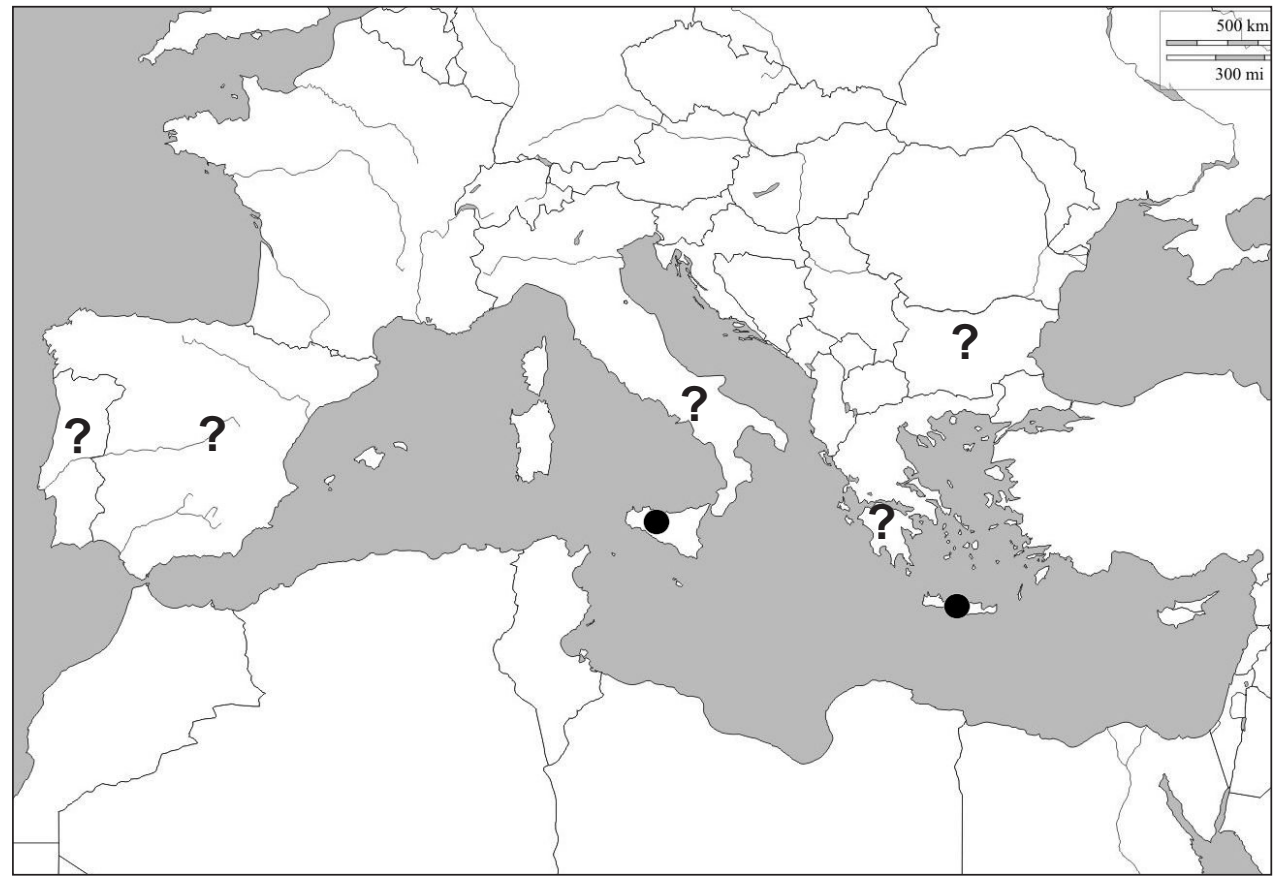

Fig. 2. Distribution of Smyrnium dimartinoi from the studied herbarium specimens (circles) and likely distribution (?).

\section{Taxonomic and chorological remarks}

The new species - as besides $S$. perfoliatum - is quite distinct from $S$. rotundifolium. It is often misidentified for the related to $S$. perfoliatum; but it clearly differs by the not winged stem, ovate leaves (not ovate-lanceolate), leaf margins crenulate, not serrate: fruit small roundish, usually 2-3 mm. From the ecological point of view, $S$. dimartinoi - at least in Sicily - appears more thermophilous than $S$. perfoliatum. With respect to the European and Middle Eastern species, like $S$. orphanidis Boiss., S. cordifolium Boiss., S. apiifolium Willd. and $S$. creticum Mill., the new taxon is distinct by several phenotypic characters and has a wider range, including Sicily, Crete and likely in other Mediterranean areas (Fig. 2).

\section{Other specimens examined}

\section{Smyrnium dimartinoi}

Sicily: Bosco del Cappelliere, Ficuzza, 18/6/2015, G. Scafidi \& F. Scafidi s. n. (PAL); Ficuzza, s. d., s. c. (PAL19975!)

Crete: Amalos, 12/6/[18]84, E. Reverchon s. $n$. [WU-Halácsy-Graecum 0076665! sub S. rotundifolium var. ovatifolium]; Amalos, bois humides, 12/6/1884, E. Reverchon 249 [WU-Halácsy-Graecum 0076664! sub S. rotundifolium] 


\section{Smyrnium perfoliatum}

Portugal: Montagne de S. Memede, Castelo de Vide (Portugal, Haut Alentejo), Atalaia, dans une ch âtaigneraie, aire d'anciennes forêts du Quercus pyrenaica, 30 mai 1975, J. Malato-Beliz \& J. A. Guerra 12549 (PAL-Gr 23458!)

Spain: Poyotello: Sierra de Segura, gorge of river Segura. Prov. Jaen, altim. 1250, Hab. Rocks and steeps screes, calcareous solis, 26/06/[19]88, B. Valdés \& al. It2388/88 (PALGr 65724!); Albacete: Sierra de Alcaraz; Chelets de la Sierra del Agua, 30S WH57, ad 1350m, in humidis ad rivulum, 28/5/1976, J. Fernández Piqueras \& al. 1129 (PAL-Gr 26599!); Caceres: Valverde de la Vera, Garganta del Naval, 30TTK84, 400 m, 5/6/1987, comunidades nitrófilas ruderales, arction A. Amor s.n. (PAL-Gr 55516!)

Sicily: Nebrodi: Biviere di Cesarò, marsh, alt. $1250-1450 \mathrm{~m}, 37^{\circ} 57^{\prime} \mathrm{N}, 14^{\circ} 43^{\prime} \mathrm{E}$, 10/06/1990, F. M. Raimondo \& al. 1887 (PAL 69225!; PAL-Gr 56576!); Nebrodi: Monte Soro, brown woody soil on quartzarenite, 1700-1800 m a.s.1., 09/06/1990, F. M. Raimondo \& al. 1820 (PAL 69226!); in humbrosis nemorum Valdemone, s.d., A. Todaro 682 (PAL79850!)

Slovenija: In graminosis ad viam inter Sežana et Dane, 360 m s.m., 2/5/1972, T. Wraber 32760 (Pal-Gr 7766!)

Bulgaria: distr. Burgas: in parte orientali collium Eminska planina ad austro-occidentem pagi Banja, alt. 350, in subumbrosis graminosis dumetorum caducifoliorum, 11/6/1973, $W$. Greuter 11123 (PAL-Gr 20143!)

Ciscaucasia: Krasnodar Territory, district Novorossiiskii, the Markhotkh range in the locality of v. Kabardinka, in forest, $400 \mathrm{~m}$ s.m., 31/05/1966, E.E. Gogina 32 (PAL-Gr 30375!)

Caucasus: Georgia orientalis, in reservato publico Zagodechi, $620 \mathrm{~m}$ s.m., silva frondosa, 11/6/1981, A. Doluchanov 1985 (PAL-Gr 39485!)

\section{Acknowledgements}

G. Domina, F. Scafidi and W. Greuter are gratefully acknowledged for the selection of herbarium specimens in PAL and PAL-Gr; E. Vitek and H. Rainer from Vienna, for the photo of the type of $S$. rotundifolium var. ovatifolium Halàcsy, which is kept in WU.

\section{References}

Boissier, E. 1872: Smyrnium. - Pp. 925-927 in: Flora orientalis, 2. - Genevae.

Conti, F., Abbate, G., Alessandrini, A. \& Blasi, C. 2005: An annotated checklist of the Italian vascular flora. - Roma.

Gómez, D. 2003: Smyrnium L. - Pp. 144-145 in: Nieto Feliner, G. S., Jury, S. L. \& Herrero, A. (Eds.), Flora Iberica, 10. - Madrid.

Fiori, A. 1925: Smyrnium L. - P. 95 in: Nuova Flora analitica d'Italia, 2. - Bologna.

Halàcsy, E. 1901: Smyrnium L. - P. 658 in: Conspectus Florae Graecae, 1. - Lipsia.

Miller, P. 1768: The Gardenerers Dictionary, Ed. 8. - London.

Pignatti, S.1982: Smyrnium L. - P. 187 in: Flora d'Italia, 2. - Bologna.

Spadaro, V., Raimondo, F. M. \& Mazzola, P. 2015: Diversity of Smyrnium perfoliatum (Apiaceae) in Sicily. - P. 156 in: Abstracts 110 SBI Congress, Pavia, 14-17 September 2015. 
142 Raimondo \& al.: A new species of Smyrnium (Apiaceae) related to S. perfoliatum.

Strid A., 1986: Smyrnium L. - P. 672 in: Mountain Flora of Greece, 1. - Cambridge.

Tutin T. G., 1968: Smyrnium L. - P. 328 in: Tutin, T. G., Heywood, V. H., Burges, N. A, Moore, D. M., Valentine, D. H. Walters, S. M. \& Webb, D. A., Flora Europaea, 2. - Cambridge.

Addresses of the authors:

Francesco Maria Raimondo ${ }^{1}$, Pietro Mazzola ${ }^{2} \&$ Vivienne Spadaroㅇ,

${ }^{1}$ Dipartimento STEBICEF, Università di Palermo, via Archirafi, 38. - 90123

Palermo, Italy. E-mail: francesco.raimondo@unipa.it, vivienne.spadaro@unipa.it

${ }^{2}$ Dipartimento SAF, Università di Palermo, via Archirafi, 38. - 90123 Palermo, Italy.

E-mail: pietro.mazzola@unipa.it 